\title{
The social construction of Paul's apostolic leadership in Corinth
}

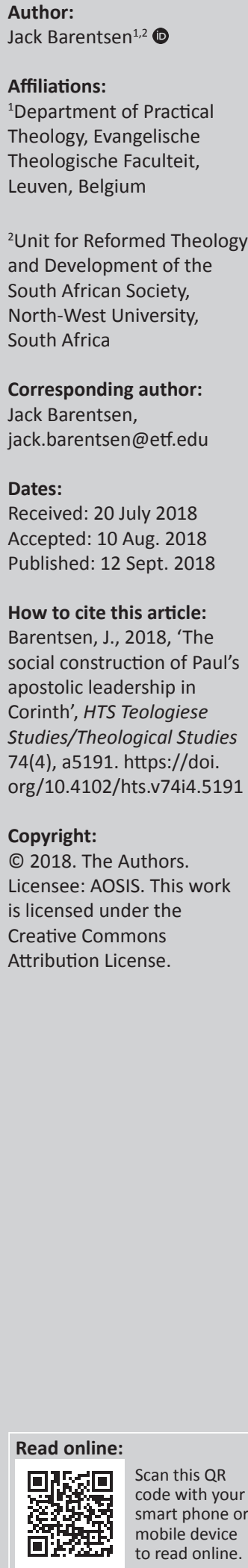

In a climate of institutional change and loss of authority, it is urgently needed to rethink the legitimacy of religious authority. This article offers a case study of Paul's authority claims in Corinth, using French \& Raven's theory of social power, to offer new insights into the construction of religious leadership. Paul negotiated renewed acceptance as Corinth's founder and apostle by appealing to legitimate power that he was a better leader than Moses, even Christ's ambassador, and by undermining the legitimate power of his opponents who claimed Jewish descent and apostolic miracles as key leadership markers. Similarly, Paul appealed to referent power by portraying his suffering as a mark of Christ-embodying leadership and undermined the referent power of his opponents by denouncing status, patronage support and rhetoric as legitimation for leadership. Paul did not appeal to other power bases (informational, expert, reward and coercion), because he could not be sure to outrank his opponents on those counts. This analysis suggests that religious authority in the form of Paul's founding apostleship was difficult to comprehend and embed in the social and cultural structures of Corinth at that time. Paul needed to engage in intense contention and negotiation to construct a socially and culturally viable model of leadership that would do justice to his vision of Christian identity. As a corollary, the evidence of the intensity of this conflict at various levels throughout the epistle can be interpreted as supporting the literary unity of the epistle.

\section{Introduction and approach}

The current climate of deinstitutionalisation and church decline significantly affects church leadership. Church leadership hierarchies seem antiquated compared to modern styles of leadership - at least in Western societies - and crumbling institutional structures become the backdrop for a loss of respect for and authority in church leadership. It is urgently needed to rethink the structure and legitimacy of pastoral leadership.

It is not sufficient to simply focus on the character or skills of the pastoral leader, or to identify a few key tasks that effective leaders should perform. Many books do just that (Herrington, Bonem \& Furr 2000; Hybels 2012; Maxwell 1999), but they do not address these pressing issues. Alternatively, awareness is rising that leaders are part of dynamic and complex group processes in interaction with the social context. For instance, some social scientific leadership research applies complexity theory and social constructivist models to the study of leadership (Uhl-Bien, Marion \& McKelvey 2007).

A constructivist portrayal of pastoral leadership starts with the observation that individuals participating in the faith community are by their very participation co-creating the organisational reality of the community (Tierney 1996:372). This reality is often multi-vocal and unstable, so that 'the idea of leadership becomes contested, and the assumption about what constitutes good leadership is open for interpretation and redefinition'. Tension within the community exists over who gains privilege and who is silenced, who is 'in' and who is 'out' (Tierney 1996:374-75). This construction and the contests of pastoral leadership are often shaped by discourses and social representations that frame the interaction between community members. 'Communicative practices talk, discourse, and other symbolic media - occasioned by the context are integral to the processes by which the social construction of leadership is brought about' (Fairhurst \& Grant 2010:174-175).

Studies like those of Holifield (2007) and Heitink (2001) demonstrate how pastoral leadership structures developed with a degree of fluidity through various historical periods and within

Note: This article was originally presented under the title, 'Paul's Authority Claims and Their Reception in 2 Corinthians,' at the SBL Seminar on 'Authority and Influence in Biblical Texts' at St. Andrews University, Scotland, on 09 July 2013, by the invitation of Prof. Dr Jan van der Watt. 
various denominational contexts. One might agree that this fluidity demonstrates the constructivist nature of these leadership structures as they adapted to their times and cultures. However, the difficult ecumenical debates on church authority demonstrate that a constructivist understanding of church leadership is hardly a common occurrence. Often, appeals are made to the biblical language

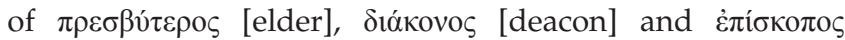
[overseer] as if they denoted clear, essentialist categories of leadership in support of particular modern structures of church leadership.

In this article, I offer a study of Paul's leadership language in 2 Corinthians which reveals the ways in which Paul, his addressees and his opponents constructed competing visions of what counts as good leadership. In this letter, ${ }^{1}$ the typical

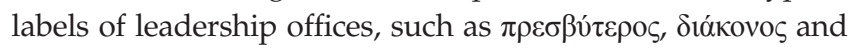
$\dot{\varepsilon} \pi \dot{\sigma} \sigma \kappa о \pi \mathrm{s}$, are absent, ${ }^{2}$ so that the interpreter is forced to find another entrance into the leadership discourse of the letter. Based on recent scholarship that sees leadership as a social construction by means of social and communicative interaction, I propose to investigate the interactive processes evident in 2 Corinthians that define leadership at a specific place and time.

This study will thus consider how Paul's discourse in 2 Corinthians (de)constructs the vision and roles of leadership prevalent within the Corinthian community, as he shapes the identity and boundaries of the faith community in relation to the surrounding Greco-Roman culture. Paul offers an alternative vision for leadership as part of a normative leadership contest with Corinthian believers and their local or itinerant leaders over what was to count as faithful Christian leadership in the community. This leadership construction is both social and theological, both cultural and religious, and concerns the socioreligious identity of the community (Barentsen 2011, 2016). I will gratefully use the knowledge now available about the sociocultural setting of the Corinthian community (Chow 1992; Clarke 2000; Theissen 1982), while my main analytical tools will derive from theoretical models based on contemporary leadership and social scientific research. This study blends New Testament approaches with approaches more familiar in Practical Theology.

\section{Paul's leadership career in Corinth}

A brief description of Paul's leadership career in Corinth is my starting point. After an initial 18 months of founding activity in Corinth (50-51 AD, Ac 18:1-17), Paul left to continue his work elsewhere. In his absence, Apollos advanced the work in Corinth for several months or years (Ac 18:27-19:1a, 1 Cor

1.Or letters: Talbert assumes that the literary unity of 2 Corinthians has generally been abandoned (2002:6-12), while Stegman (2005) and others argue for its rhetorical and theological unity.

2.It would be an argument from silence to now conclude that such offices must not yet have been ordered in Corinth at this time. Hanges (2011) argues to the contrary yet have been order in Cor that Paul as a founder or a transplanter of a religious cult would have been expected to set guidelines for ritual, membershi on his comparative study of other ancient Greek texts about founders of religious cults. Thus, it is better to argue that, as the letter is mostly issue-driven, the absence of these labels implies that the structures of leadership that are denoted by these labels were not themselves an issue to be addressed.
3:5-9). ${ }^{3}$ When Paul wrote our 1 Corinthians (ca. 55 AD), Apollos was no longer there, and the church had developed subgroups identifying with their key Jewish leaders Paul and Apollos, and also with Peter and perhaps even Christ. ${ }^{4}$ These subgroups resulted from the church's expansion, and they engaged in rivalry as the Corinthian way of maintaining subgroup connections (Barentsen 2011:78-86). This means that during his absence, Paul's leadership status had shifted from community-wide respect to leadership of only a subgroup; he can no longer assume that he has the authority to address the entire community. This at least partially explains the cautious argumentation in 1 Corinthians $1-4$, where he needed to tread carefully to re-establish his own leadership position for the whole church.

Unfortunately, Paul's letter seems to have been ineffective (Barentsen 2011:114-15; Mitchell 1991:303), because intense conflict erupted with the church after the letter's arrival. Although the events between our 1 and 2 Corinthians are difficult to reconstruct, 2 Corinthians speaks about a painful visit (1:23-2:3) and a tearful letter (2:3; 7:12) before Titus was able to bring about reconciliation $(7: 6,13)$. Whatever the causes of this conflict, it appears that Paul's leadership came under intense criticism, so that he was almost completely marginalised as a community leader (Barentsen 2011:115-125). He then engaged in a painful negotiation process that enabled him to regain the trust of most of the congregation, as evidenced by the conciliatory tone of 2 Corinthians $1-7$ and his renewed efforts at completing the collection in 2 Corinthians 8-9. I will argue that the change of tone of 2 Corinthians 10-13 provides further evidence of nearly complete reconciliation - a reconstruction that is intensely debated (Horrell 1996:296-312; Martin 1986:298ff.). In this section, Paul rhetorically marginalises the few remaining opponents who were as yet unconvinced by his negotiations, a rhetorical strategy that - as we will see - can only be successful when the majority of the community is in harmony with the speaker.

In brief, Paul started off winning allegiance as the founder of a new religious community but soon found himself relegated to the status of a subgroup leader of the growing congregation and was caught in a spiral of conflict, nearly losing his entire leadership footing in Corinth. Surprisingly, he was able to regain his position as the founder and apostle of the entire community, with a few marginalised exceptions. Note that Paul was not in a position to enforce loyalty or to coerce the believers into following his leadership. He was disenfranchised in Corinth, had no personal local power base and needed to negotiate and persuade in absentia to relegitimate his leadership. His earlier preaching and demonstrations of divine power had lost their persuasive powers.

3.The historical importance and value of the book of Acts is an issue of considerable debate, but there is a general consensus about the period of Paul's ministry in Corinth, and the dating of the Corinthian correspondence (DeSilva 2004:560ff.).

4.The exact identification of the subgroups and its leaders remains an issue of debate. It is doubtful whether Peter visited Corinth before the writing of 1 Corinthians. Paul lists 'Christ' as possible leader that people identified with, perhaps as some resisted lists 'Christ' as possible leader that people identified with, perhaps as some resisted
identifying with merely human leaders and claimed a more spiritual lineage (see identifying with merely
Barentsen 2011:78-80). 
This raises the question: 'How did Paul succeed in convincing the Corinthians of the legitimacy of his leadership and winning their allegiance in competition with colleagues and rival leaders?' This question can be subdivided in a number of subsidiary questions: (1) What authority claims does Paul make? (2) How were these authority claims received by the Corinthian believers? (3) How does this explain Paul's eventual success?

\section{The lenses of social identity theory and social constructivism}

Traditional studies on Paul's leadership located the fluidity in his leadership status in Corinth in an alleged charismatic phase of congregational life, which was eventually overtaken by institutionalising tendencies (Blasi 1991; Von Campenhausen 1997). However, this Weberian dialectic between charisma and institution has not been able to adequately account for the phenomena under investigation (MacDonald 1988:60). Further application of social science models resulted in more refined studies on Paul's use of power and authority as expressed in the corpus Paulinum (Ehrensperger 2007; Holmberg 1978; Schütz 1975), while the practice of (local) leadership in Corinth has also been studied in detail (Chow 1992; Clarke 2006). But Paul's leadership career in Corinth has not yet been investigated as such. Horrell comes closest in studying the ethos of the Corinthian correspondence as a formulation, reformulation and transformation of the symbolic world that Paul constructs (Horrell 1996:55-59), but his focus is more on the community than on Paul and his exercise of leadership and power.

A study of Paul's leadership career in Corinth provides a window of insight into how he constructed his leadership position as part of his vision of the Christian identity of his communities. In a dialectical manner, his view on the identity of the community legitimised his own leadership role and vice versa. Thus, 2 Corinthians is not merely the plea of a solitary leader before a community, but represents a dynamic communication process where both the group around Paul and the communities in Corinth have an interest in maintaining their relationship (Ehrensperger 2007:56). Paul's leadership is shaped and transformed through various processes of social negotiation and his authority in Corinth is socially constructed. This is not to say that his authority rested only on social construction, but that - whatever we might believe about the religious sources of his authority - at least it took a process of social interaction and construction to allow his view and practice of authority to take social root. In the investigation of Paul's leadership negotiations, this article will thus utilise theories of social identity and leadership from a social constructivist stance.

\section{Paul's authority claims (leader self-presentation)}

In order to answer the question: 'How did Paul succeed in convincing the Corinthians of the legitimacy of his leadership and winning their allegiance in competition with colleague and rival leaders?,' Paul's central authority claims need to be investigated.

In some ways, discussing Paul's authority claims in 2 Corinthians is to discuss the entire letter. In the opening of the letter, Paul mentions his suffering for and comfort from Christ which benefit the Corinthians (1:3-11), defends his integrity and pastoral care in cancelling an intended visit (1:12-2:4) and provides instruction for the restoration of a repentant believer (2:5-11) - all of which Paul interprets as Christ's victory, even if at his own expense (2:12-17). This victory then introduces Paul defence of his apostolic ministry, which takes up and expands the issues of suffering, integrity and restoration, and adds a comparison of Paul's and Moses' ministry (3:1-7:4). As an ambassador of Christ (not from Jerusalem), Paul pleads for renewed loyalty to his message, ministry and leadership (5:11$7: 4)$. His instructions for the Jerusalem collection (2 Cor 8-9) affirm his role in the network of churches of which Corinth was a part, as well as his respect and concern for the Jerusalem church. Most of these themes return again in chapters 10-13, but now sharper as he defends himself explicitly against certain charges from Jewish-Christian teachers from Israel that had gained influence in Corinth. This article will focus on the central authority claims of the letter in order to trace Paul's construction of his apostolic leadership.

\section{A more glorious ministry than that of Moses}

An audacious authority claim is Paul's contention that the ministry of the Spirit - which he purports to exercise - has greater glory than the ministry of Moses. He pictures the latter as a ministry of death and condemnation and the former as a ministry of life and righteousness (3:7-11). This claim surprises because Moses is referred to only twice in 1 Corinthians (9:9; 10:2), both times with positive connotation, suggesting that Moses' person and the Mosaic Law were not an issue of debate at that time. How could this have become an issue in 2 Corinthians? Just prior to this claim, Paul referred to opponents as 'peddlers of God's word' (2 Cor 2:17) who carried letters of recommendation (3:1), and contrasted this with the positive effects of his own ministry as bringing about Spirit-filled change in Corinth (3:2-3). Paul amplifies the contrast by discussing the positive effects of his own glorious ministry of the Spirit, compared to the negative effects of veiled understanding and hardened minds through the ministry of Moses (3:7-18). This comparison indirectly associates his Corinthian opponents with his negative evaluation of the ministry of Moses (Martin 1986:46), raising the question whether the opponents, at least some of whom were itinerant Jewish-Christian teachers from Israel (cf. 11:22-23), had introduced a different perspective on Moses' ministry in Corinth during Paul's absence. The answer can only be speculative, for we know too little about the identity and teaching of these opponents (Burtchaell 1992). But at least this much can be said, that Paul's theological comparison of the ministries of Moses and the Spirit served to delegitimise the status and influence of his opponents as those who were still ministering like Moses, and to legitimise his own ministry as operative through the Spirit of Christ (Martin 1986:55). 
This authority claim is counterintuitive, for written letters of recommendation from Jerusalem authorities would be a better cultural fit and more impressive to the Corinthian church, most of whom were of lowly social status; by contrast, the changes in their own lives as evidence of Spiritempowered ministry must have appeared unimportant in matters of authority. Moreover, the ministry of Moses had a long and venerated tradition that conferred an air of antiquity and legitimacy on the Christian message, compared with which Paul was a recent upstart. Thus, Paul's argument to represent a more glorious ministry than Moses stakes out a theological authority claim validated by the religious transformations of the majority of the Corinthian believers, who were of lower social status, but that would be easily contestable on social and religious grounds by the few Corinthian believers of higher social status.

\section{Suffering like Christ}

Paul's discourse on self-sacrifice and suffering represents another significant authority claim. These themes run throughout 2 Corinthians (1:3-11; 4:7-18; 6:4-10; 11:23-28; $12: 7)$, and do more than simply plead for loyalty on the basis of Paul's suffering for Christ. In essence, Paul $^{5}$ presents himself as suffering like Christ, not simply for Christ, as the primary basis for the legitimacy of his leadership in Corinth. His suffering enables him to minister Christ's comfort to the church (1:5-6). Could one minister such comfort without such suffering (Barrett 1973:62)? Through suffering, the death and life of Christ are physically manifested in Paul, enabling him to bring life to the community (4:10-12). Could one model the life of Christ to the community without also participating in his death? Through suffering, Paul commends himself and his team as 'servants of God' (6:4), thereby demonstrating their affections for the Corinthians (6:11-12). How could one demonstrate affection without self-sacrifice on behalf of others? Through suffering, Paul's weakness becomes evident (11:29-30), so that his influence in leadership evidently derives from the power of Christ and not from personal power (12:9-10). What better way to avoid confusing social leadership status and divine influence? In all these passages, Paul frames his suffering as a key component of his calling and ministry, aligning his own ministry with the suffering servant of Isaiah and the ministry of Christ, thereby legitimising his spiritual leadership among the Corinthians. ${ }^{6}$ Interestingly, modern psychological research in social identity and leadership has pointed out that leader self-sacrifice portrays the leader as prototypical for the community, and thus enhances leader effectiveness (Van Knippenberg \& Van Knippenberg 2005).

This authority claim, too, would be contested. Greek models of leadership depended on status and patronage, which also

5.The text is written in the first person plural, suggesting that Paul speaks for himself as well as his team members. To avoid cumbersome references to 'Paul and his team', I refer to 'Paul' in order to highlight the effect of the argumentation on Paul's leadership status.

6.Martin suggests that for Paul's opponents, Jesus was more like a second Moses rather than a suffering servant (Martin 1986:340), which, in turn, suggests that Paul's portrayal of himself as suffering servant not only legitimised his own suffering because of its connection to Christ, but also positioned Christ as suffering servant because of its connection to
rather than a second Moses. influenced leadership structures in Corinth (Clarke 2006). Such severe suffering as Paul describes would vouch against one's leadership status, and would not be expounded upon so publicly and unashamedly as in his letter. Moreover, this suffering may well have been interpreted as a lack of divine approval for Paul's apostolic ministry (Long 2004:119). This extended description and defence of his suffering, a theme absent from 1 Corinthians, probably implies that he was publicly criticised for this as a disqualifier of his apostolic leadership. This forced him to defend his suffering more openly than he would otherwise have done, but as he does so he frames his openness as a demonstration of his sincerity, integrity and lack of deceptive motive (4:1-3). However, Paul's most important defence is his portrayal of his suffering as an image of the death and life of Christ in his own physical body (4:10-11), thus embedding his own suffering as a leadership model in their corporate understanding of what it meant to be a believer and member of the Christian community. That is, Paul turns accusations that his suffering disqualifies him from leadership on their head, arguing that faithful leadership must embody the sufferings of Christ in self-sacrificial forms of leadership rather than relying on status, patronage and privilege.

\section{Ambassador of reconciliation}

After distinguishing himself as a minister of Spirit-filled transformation as contrasted with Moses' ministry of death, and after pointing out the Christological value of his suffering for faithful leadership in the community, Paul claims to serve as Christ's envoy or ambassador. The clause 'Y $\mathrm{x} \dot{\varepsilon} \rho$ X $\rho ı \tau \tau o \tilde{~ o u ̃ v ~}$ $\pi \rho \varepsilon \sigma \beta \varepsilon v ́ o \mu \varepsilon v$ ('we are ambassadors for Christ,' 5:20, English Standard Version) refers to the performing of ambassadorial services, implying that Paul claims to bring a divinely authorised message of reconciliation to the Corinthian church ('God making his appeal through us') (eds. Balz \& Schneider 1990 [vol 3]:147). This is more than simply being Christ's messenger, as an envoy exercised the authority of the sender, and 'to disregard or insult the envoy was to disregard or insult the sender' (Harris 2005:445-46). Thus, if the Corinthians were to turn their back on Paul, they would also turn their back on the divine message of reconciliation (Garland 1999:298)! Paul, then, is not proclaiming the gospel to unbelievers, but he pleads with his audience to be reconciled with himself and thus also with God in order to remain connected with Christ's work of reconciliation (Gloer 1989:403). This is undoubtedly one of the strongest authority claims that Paul puts forward in his letter.

Yet, this authority claim is not simply based on the hierarchical leadership structures of the ancient world that are part of this image of ambassadorship. Paul's emphasis on suffering like Christ just preceding this imagery (see the section above), and his later defence of his suffering (11:23-29), moderate any hierarchical tendencies that usually accompany the image of ambassador. Moreover, Paul's self-sacrifice on behalf of the community vividly demonstrates his self-less commitment to serve the community with little or no personal profit motive involved, in spite of criticism to the contrary. 
Paul's claim to be Christ's ambassador is at the centre of his plea for reconciliation between the Corinthian community and himself. It is significant that he pens these words after hearing the good news from Titus that the Corinthians repented and are once again eager to receive him (7:6). When Paul cites the Psalms that 'now is the favourable time' (6:2; Ps $32: 6 ; 69: 13$; cf. Isa 55:6), this is more than a figure of speech, for he knows that this favourable time has indeed come. He knows that his plea for reconciliation has already been taken to heart even before he pens these words.

Counting on the positive reception of this authority claim, Paul adds a charge to dissociate from yet unrepentant troublemakers. The much disputed passage, 6:14-7:1, has its difficulties in language and setting, for which reasons it has been considered as a non-Pauline interpretation by many scholars (Bieringer 1994:551-570). It admittedly appears as a digression, for instance, as an appeal to Christians to refrain from worldliness and idolatry (Talbert 2002:209). Yet, considering the traditional nature of this passage and its language, Paul may well have used it to press home his plea for loyalty by encouraging the Corinthians to prove their loyalty to Paul by showing disloyalty to his opponents. For instance, the exhortation to turn back from idolatry couched in the language of covenant faithfulness (Long 2004:169-170) may well be an oblique reference to the inappropriate appreciation among the Corinthians for social status and rhetoric as markers of authority. Paul's charge to repent of these things then becomes a charge to disengage from those who still hold to these inappropriate cultural values. That is, this passage makes excellent 'political' sense at this precise location in a letter dedicated to re-establishing Paul's apostolic authority in competition with rival leaders.

\section{The value of Jewish descent}

In the section in 2 Corinthians 2:14-7:4, Paul presents his own defence of his credentials and the legitimacy of his apostolic role in Corinth. After the chapters on the Jerusalem collection (2 Cor 8-9) that demonstrate his respect for and allegiance to the Jerusalem church (Barentsen 2011:129-130; Stenschke 2015), Paul engages directly with the authority claims of his opponents in 2 Corinthians 10-13.

One such authority claim depends on Jewish descent. Paul readily conceded that his opponents were of reputable Jewish descent, but he claimed equality on the basis of his own Jewish heritage (11:22-23). This authority claim probably had a track record in Corinth, because the subgroups that had developed before even the writing of 1 Corinthians all identified with Jewish leaders (1 Cor 1:12). Perhaps, Paul was despised for his Diaspora origins rather than being of 'pure' Jewish descent from Israel (Harris 2005:794), but his defence makes no reference to this. To counter this claim, Paul does not claim superiority to his opponents, as he did in the first half of 2 Corinthians, and as he well might have, considering his former elite status as Pharisee. Although he uses his Pharisee status to demonstrate his (former) commitment to the Mosaic law in another context (see Phil 3:5), he refrains from doing so now. In the current Corinthian context, with Jewish-Christian teachers emphasising adherence to the Mosaic Law in some form, Paul's status as Pharisee would at best be a point of identification with his Jewish-Christian opponents and not a point of distinction. More likely, the gospel Paul proclaimed was constantly under suspicion for being critical of adherence to the Mosaic Law, so that a former status as Pharisee would likely be framed as betrayal to Moses and count against Paul's authority, instead of in favour of it. Paul thus has to opt for an alternative rhetorical strategy. In order to identify with the Corinthian congregation of mixed Jewish and gentile descent, he has to minimise the importance of Jewish heritage as a factor in legitimising authority. Thus, he frames this authority claim as foolish boasting according to the flesh (11:18-21). This foolishness is evident in the physical markings of his suffering, as 'tracings of whips and magistrates' rods' on his scarred body did not mark 'martial valor' but of 'a servile body, insignia of humiliation and submission' (Glancy 2004; Joubert 2015). No Corinthian leader of the right social and cultural mind would boast of such humiliating markings; this was foolish indeed. This rhetorical strategy reinforced the previous normative image of the suffering servant as self-sacrificial leader and presents unexpected physical evidence for Paul's status as primordial servant of Christ in Corinth (11:23ff). Paul thereby neutralises Jewish heritage as basis for any authority claim, voiding any legitimacy that might have been derived from it in Corinth. Moreover, once again, he sides with the majority of the Corinthian believers, of gentile descent of low social status, over against the Corinthian and Jewish elites in his social construction of authority.

\section{A true apostle}

Another authority claim relates to apostolic status and leadership. Paul defends his own status as true apostle of Christ against charges that he is inferior to 'these superapostles' (2 Cor 12:11-12). Although the identity of the 'superapostles' is debated (see Harris 2005:73-77), Paul's argument that he is on a par with these apostles suggests that this label refers to the manner in which his rivals compared the Jerusalem Twelve with himself before the Corinthian community (Harris 2005:746-748). That is, Paul's rivals claimed support for their teaching from the Jerusalem apostles, whom they portrayed to the Corinthians as the most excellent apostles, while they depicted Paul as a much inferior apostle, continually humiliated by physical misfortune, in order to discredit Paul's teaching and status within the community.

Paul responds that he is equal to the Twelve as demonstrated by the visions and revelations he had received (12:1) and by his miraculous powers (12:12). These features were well known in Corinth, because they had personally witnessed Paul's miracles during his initial ministry in the city and had received teaching from him that originated in revelations from the Lord (see also 1 Cor 11:23, 15:3) (Garland 2003:683-687; Thiselton 2000:1186-1187). Paul thus argues that his apostolic 
status is independent from the acknowledgement or approval of the Jerusalem apostles.

However, he is unwilling to make much of such supernatural claims. Apparently, the Corinthians venerated revelations and miracles as marks of divine approval (Martin 1991), and had begun to view them as leadership status markers, along with such features as eloquent speech and patronage sponsorship. Even though Paul claims equal authority in Corinth with the Twelve, based, in part, on his own revelations and miracles, Paul appears to consider the Corinthian veneration for such supernatural authority claims to be deficient (Garland 1999:529), and sets about to correct their perception of apostolic status. He speaks with great hesitation about his visions (12:2-5), at first attributing them to 'a man in Christ'. When it becomes clear that Paul himself was the man receiving the visions, he immediately speaks about a 'thorn in the flesh' that the Lord did not remove in spite of his prayers to keep him from being conceited (12:7-9). He would rather boast in weaknesses and suffering than in glorious visions. Next, when he refers to his miracles in Corinth, he immediately excuses himself for not charging a fee or accepting patronage (12:1213). He is clearly aware of the qualifications of a true apostle in terms of revelations and miraculous powers, but he refuses to turn these qualifications into markers of spiritual status and leadership in the community.

In essence, Paul refuses to claim authority on the basis of revelations and miracles, while his opponents insisted on such qualifications and may have criticised him for a lack of them. Paul is then forced to claim equality with the Twelve in order to be seen as superior to his opponents in Corinth (12:11-13) (Martin 1986:427-28), but he does not push this equality as a claim for his own apostolic authority in Corinth. Instead, he downplays the marks of 'true apostleship' as basis for authority, and focuses instead on the presence of Christ's power in his weaknesses and suffering, once again reiterating suffering and self-sacrificial leadership as primary legitimation of his apostolic leadership in Corinth, thus implicitly empowering lower social class Corinthian believers to play significant or even leadership roles within the community.

\section{Summary}

Paul's authority claims are worked out positively in 2 Corinthians 1-7. He presented his ministry as more glorious than that of Moses, while his suffering made him a leader like Christ. Also, his role as an ambassador made him an authoritative spokesman for Christ, affording him the status of exhorting the Corinthians to be reconciled with God and himself and to dissociate themselves from his unrepentant opponents. Paul's authority claims are worked out as corrective in 2 Corinthians 10-13, where he compares favourably with the Jewish descent of his opponents, but this turns out to be irrelevant as leadership marker, and where revelations and miraculous powers demonstrate his equality with the 'super-apostles', which turn out to be less important for Paul's self-presentation as an apostolic leader than his weakness and suffering on behalf of the community.

\section{The reception of Paul's authority claims (follower response)}

After surveying Paul's most significant authority claims in 2 Corinthians, I now turn to the second question, 'How were these authority claims received by the Corinthian believers?' This may appear speculative, until we realise that Paul wrote this letter as part of an elaborate communication process. The letter reflects the latest news from Corinth which he received through the mediating efforts of Titus, which indicated the readiness of the Corinthians, at least the majority, to be reconciled to Paul as their founder and apostle (7:5-16). And yet, some opposition apparently remained. This implies that the reception of Paul's authority claims was mixed at best.

This mixed acceptance is reflected in the self-presentation of Paul's leadership style. Firstly, he adopts a strategy of persuasion towards the majority: he has authority for building up, not tearing down $(10: 8 ; 13: 10)$. He does not domineer, but helps them to stand firm in their faith (1:24). Thus, he spared them by cancelling his intended visit (1:23) and by writing them out of much affliction and anguish (2:4). He expresses his love and affection for them (6:11-13; 7:2; 11:11), which is demonstrated through self-sacrifice (6:4). He does not burden them with financial concerns $(11: 9 ; 12: 13-16)$ but commits them to Christ as if it concerned a betrothal (11:1). That is, Paul wants to serve them in their Christian living.

Secondly, Paul adopts a strategy of empowerment to assist the majority in answering those who accuse him. He gives them 'cause to boast about us, so that you may be able to answer those who boast about outward appearance and not about what is in the heart' $(5: 12)$. Assuming that they are ready to

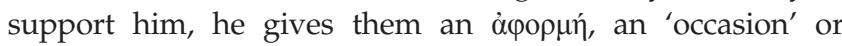
'opportunity,' a word often occurring within a polemical context, to rally to his defence (Danker et al. 2000:s.v). It is not so much his personal example as it is his embodiment of the gospel (5:13-15) that he puts forward as his defence. In doing so, he provides images or arguments for his Corinthian supporters to defend him and resist his opponents. Similarly, Paul's discussion of his Jewish descent and his apostolic credentials (discussed above) enabled the Corinthians to resist authority claims on that basis. His denouncement of the practice of depending on patronage and eloquent speech as markers of spiritual authority $(12: 16-18 ; 10: 10)$ enabled the Corinthian believers to resist elitist forms of dominance. Thus, in countering such comparisons and accusations, he addresses the congregation perhaps more so than his critics in a strategy of empowerment, enabling the Corinthians to follow through in their loyalty to himself and to dismantle their loyalty to his opponents in order to disengage from them.

Thirdly, Paul adopts a very directive and authoritative style when addressing his remaining opponents. Some of this is still indirect; for instance, when he appeals to the Corinthians to repent so that he will not be humbled to the point of repentance when he comes (12:20-21), or when he hopes that he will not have to be severe in the use of his authority (13:10). The military metaphors - the victorious triumph of Christ in 
which he participates (2:14-16), defensive and offensive weapons (6:7), offensive weapons for divine warfare $(10: 4-5)$ - sound increasingly severe as a warning to his opponents. Occasionally, he directly warns his critics that he will do what he writes in his letters (10:11) and that he will not spare them if they do not repent $(13: 2)$.

In sum, Paul acts mostly according to persuasive and empowering leadership styles. Even when he speaks authoritatively, his appeals and warnings are often indirect. It indicates his awareness that the reception of his authority claims in Corinth was mixed at best, even if the balance was strongly in favour of acceptance.

\section{Bases of power}

We can advance the study of Paul's authority claims and their reception by analysing them with the aid of the concept of bases of social power, as developed by French and Raven (1959:150-167; see also Raven 2008:2-3). They studied social power as the potential to influence others to bring about change, depending on the resources someone has available. They identified six bases of power:

- Informational power operates when a leader shares information with a follower, resulting in cognitive change, which then leads to behavioural change of the subordinate independently from the leader.

- Reward and coercive power relate to the ability of the leader to provide positive or negative incentives to secure the cooperation of the followers, which requires continuing surveillance to be effective.

- Legitimate power relates to the follower accepting the right of the leader to require compliance, so that he feels obliged to comply.

- Expert power involves trusting that the leader has superior knowledge or experience about what is best in the circumstances, and willingness to follow on that basis alone. This is somewhat different from informational power, which includes cognitive change, meaning that the follower understands the reasons for the change in behaviour.

- Referent power means the follower identifies with the leader as a model to emulate.

The last three bases of power lead to behavioural change that is dependent on the leader's continuing direction, but does not necessarily require surveillance.

In the typical fashion of social science research, these social bases of power can be utilised as sensitising concepts that allow a researcher to analyse and code research texts accordingly (Van den Hoonaard 2008). Typically, research texts include numerous transcriptions of interviews, speeches or sermons, relevant organisational documents or extended case study descriptions. In this study, the focus is on just one research text, namely, 2 Corinthians, but the process of coding and collecting relevant information for each sensitising concept from various parts of the text can be carried out in similar fashion (Bryman 2012:465-489). I worked through the letter in this fashion, collecting and tabulating, Paul's leadership claims as well as the possible (often implicit) counterclaims of his opponents. My results are presented in Table 1.

\section{Discussion}

Although the categorisation of specific elements of the letter as this or that social basis of power could be debated, overall, the results provide some valuable insights into Paul's understanding of leadership and authority.

It appears that Paul's central authority claims (as discussed above) relate primarily to legitimate and referent power. Four of his central authority claims fit in the category of legitimate power. His ministry is superior to that of Moses, so those falling back on Mosaic patterns of ministry have less legitimacy as leaders than Paul - which presumably would apply to his opponents. Paul is also Christ's envoy, compared to the opponents who can claim to be envoys from Jerusalem, perhaps even from the Twelve, but not directly from Christ. Paul's Jewish descent plays a role only to show his equality with his opponents with similar claims. And Paul's ministry as an apostle makes him the equal of the Jerusalem apostles. His opponents, on the other hand, boast of letters of recommendation, which Paul could not produce; instead, he creatively changed the terms of the debate by arguing that he had no need of such letters, because as the founding father he could claim the religious transformations of the Corinthian believers as his letter of recommendation. Paul thus claims legitimacy on account of the visible work of the Spirit through his ministry to the Corinthians, while his opponents rely on organisationalarrangementssuchasletters of recommendation and patronage structures as well as on ancient synagogue traditions to preach in the tradition of Moses.

What could account for this different perspective on legitimate power? Perhaps, it reflects different stages of community formation in Jerusalem and in Corinth, the latter faith community being only 6 years old, the former around 25 years at the time of writing. Such an argument would presuppose that the age difference would account for certain features of structuring or institutionalising. This is possible, and would need to be investigated by studying such structuration processes in the ancient world. Horrell offered a sociological perspective along traditional developmental lines (Horrell 1995; 1997), but a recent study by Hanges of ancient Greek narratives about the founders of religious cults provides a new perspective. He demonstrates that Greek founder traditions always present the cult founder as selected by a deity, commissioned to found (or transfer) the cult in a new location, as well as to structure the community's rituals, membership and lifestyle, thereby instituting certain formal structures and leadership practices from the start (Hanges 2011). Thus, it is difficult to substantiate that the time differential between Jerusalem and Corinth communities each of which claimed continuity with earlier Jewish communities - adequately accounts for this difference in 
TABLE 1: Authority claims and their social bases of power in Corinth.

\begin{tabular}{|c|c|c|}
\hline Power basis & Paul's authority claims & Most likely opponent claims \\
\hline Informational power & $\begin{array}{l}\text { - News of Paul's afflictions in Asia }(1: 8-11) \\
\text { - Explaining Paul's absence from Corinth }(1: 15-22) \\
\text { - Paul's intention to spare the Corinthians }(1: 23-2: 4) \\
\text { - Paul's response to Titus' report }(2: 12-13 ; 7: 5-16) \\
\text { - 'We all ... are being transformed' }(3: 18) \\
\text { - 'the open statement of the truth' }(4: 2) \\
\text { - 'We are not commending ourselves ... but giving you cause to boast about us, } \\
\text { so that you may be able to answer those ...' (5:12) } \\
\text { - 'Even if I am unskilled in speaking, I am not so in knowledge' (11:6) } \\
\text { - God will provide an escape, as he did in Damascus (11:31-33) } \\
\text { - 'Visions and revelations of the Lord' (12:1) }\end{array}$ & $\begin{array}{l}\text { - Personal knowledge of Christ's ministry and teaching, based on } \\
\text { their Jewish origins? }\end{array}$ \\
\hline Reward power & $\begin{array}{l}\text { - 'We must all appear before the judgment seat of Christ' (5:10) } \\
\text { - Honour within Paul's network of churches (and with Jerusalem church) }(8: 1-9: 15) \\
\text { - 'For it is not the one who commends himself who is approved, but the one whom the } \\
\text { - Lord commends' (10:18) } \\
\text { - 'The God and Father of the Lord Jesus ... knows that I am not lying' (11:31) }\end{array}$ & $\begin{array}{l}\text { - Good standing with the elite in Corinth? } \\
\text { - Good standing with the Jerusalem church? } \\
\text { - Favoured with Jewish teachers from Jerusalem? }\end{array}$ \\
\hline \multirow[t]{2}{*}{ Coercive power } & $\begin{array}{l}\text { - 'It was to spare you that I refrained from coming again' (1:23) } \\
\text { 'If I come again I will not spare them' (13:2) }\end{array}$ & - Threat of becoming disconnected from Jerusalem? \\
\hline & $\begin{array}{l}\text { - 'Do not be unequally yoked' (6:14-7:1) } \\
\text { - 'We destroy arguments and every lofty opinion raised against the knowledge of God' } \\
\text { - 'What we say by letter when absent, we do when present' }(10: 11)\end{array}$ & $\begin{array}{l}\text { - Through persuasion and accusation, manipulated to marginalise } \\
\text { Paul ('his bodily presence is weak, and his speech of no account' } \\
-10: 10 \text { ) }\end{array}$ \\
\hline \multirow[t]{7}{*}{ Legitimate power } & $\begin{array}{l}\text { - 'Not that we lord it over your faith' (1:24) } \\
\text { - 'We are not ... peddlers of God's word, but ... commissioned by God ... we speak in } \\
\text { Christ' }(2: 17) \\
\text { - 'Did I commit a sin ... because I preached God's gospel to you free of charge? I robbed } \\
\text { other churches ... to serve you ... and will refrain from burdening you in any way' } \\
\text { (11:7-9) }\end{array}$ & - Pride in proper patronage relationships, including sponsorship \\
\hline & $\begin{array}{l}\text { - 'You yourselves are our letter of recommendation' (3:2) } \\
\text { - 'our sufficiency is from God, who has made us ... ministers of a new covenant ... of the } \\
\text { Spirit' } \\
\text { - ' } 3: 5-6) \\
\text { - 'We refuse to practice cunning ... but by the open statement of the truth we would } \\
\text { commend ourselves' }(4: 2) \\
\text { - 'commend ourselves in every way' through suffering (6:3-13) }\end{array}$ & - Letters of recommendation from Jerusalem \\
\hline & - Better than that of Moses (3:7-18) & - In line with tradition of Moses \\
\hline & - Ambassador of reconciliation $(5: 11-21)$ & \\
\hline & 'We do not boast beyond limit in the labours of others' $(10: 15 ; 12: 12)$ & - Boasting in others' labours, no respect for mission territory \\
\hline & Jewish descent (11:22-23) & - Jewish descent \\
\hline & $\begin{array}{l}\text { - True apostle (12:11-13) } \\
\text { - Apostolic performance 'with utmost patience, with signs and wonders and mighty } \\
\text { works' (12:12) }\end{array}$ & - Apostolic authorisation \\
\hline \multirow[t]{2}{*}{ Expert power } & - 'the daily pressure on me of my anxiety for all the churches' (11:28) & $\begin{array}{l}\text { - Rhetorical skill (cf. 'For they say, His letters are weighty and } \\
\text { strong, but his bodily presence is weak, and his speech of no } \\
\text { account' - 10:10) }\end{array}$ \\
\hline & $\begin{array}{l}\text { - 'visions and revelations of the Lord' (12:1) } \\
\text { - 'the surpassing greatness of the revelations' (12:7) }\end{array}$ & - Experience from the 'first hour'? \\
\hline \multirow[t]{3}{*}{ Referent power } & 'If we are afflicted, it is for your comfort and salvation' (1:5-7) & - Jewish-Christian believers from Israel \\
\hline & - Suffering like Christ (4:7-5:10; 6:3-13, 11:24-30) & $\begin{array}{l}\text { - Respecting Corinthian patronage (cf. ‘I myself did not burden } \\
\text { you'-12:13) }\end{array}$ \\
\hline & - Ambassador of reconciliation $(5: 11-21)$ & - \\
\hline
\end{tabular}

Note: References in bold refer to the authority claims already discussed in Paul's authority claims (leader self-presentation) section.

terms of institutionalisation or structuration. Hanges points in another direction: Paul's self-presentation as a founder aligns well with Greek founder narratives in claiming legitimacy as divine envoy for transplanting the Jesus cult to Corinth, and instituting its structures and leadership. Such a self-presentation may, however, have carried less weight with the Jewish-Christian believers, who were used to the structures of Diaspora Judaism with its allegiance to Jerusalem and letters of recommendation. Did Paul frame his task as cult founder purposely along the lines of Greek founder narratives to win the allegiance of the Gentile believers while at the same time putting some distance between himself and his opponents?

Two of Paul's central authority claims relate to referent power. Instead of viewing his own misfortunes as telltale signs of Gods' disapproval, as undoubtedly they must have appeared to some, or even viewing them as suffering for Christ, he pictured them as carrying the suffering of Christ in his own body, as it were with redemptive value for the
Corinthian community for whom he had sacrificed so much. Thus, Paul presented himself as the embodiment of Christ's death and life to the Corinthians. Alongside this self-sacrifice, he placed Christ at the very centre of his message and thus at the centre of the identity of his Christ-believing communities (1 Cor 2:2; 2 Cor 3:18). This turned Paul into a powerful embodiment of his own message, a role model that could not be ignored. His opponents, on the other hand, could only claim referent power by virtue of their Jewish heritage, or perhaps by virtue of their adoption of patronage sponsorship, emulating the kind of reception and status that many Corinthians would have been envious of. Clearly, it was easier for most of the Corinthians to identify with Paul in his manual labour and his suffering than with the itinerant Jewish-Christian teachers whose heritage they could never match, and whose social status would remain beyond the grasp of most local believers. Paul's use of referent power gave him a significant social advantage over his opponents by his continuing identification with the majority of the Corinthian believers instead of with the leading elites. 
Paul differed significantly from his opponents in his use of expert power. Although he could claim expertise on account of his visions and his experience in his churches, he downplayed their value as accreditation for leadership. The opponents, on the other hand, seemed to have great respect for eloquence and presumably were well versed in rhetoric. They also enjoyed the support of Corinth's believing patrons, a further testimony to their abilities as traveling teachers (Winter 2002). It appears, then, that his opponents put great stock in their expertise as qualification for their leadership, while Paul not only downplayed it but also discredited it as a basis of for leadership in Corinth. This parallels the emphasis on referent power, which Paul used effectively to portray himself as someone that every community member could identify with in their desire to imitate Christ, even if leaders and the elite might have frowned at his lack of status and expertise.

Paul used informational power to inform the Corinthians of his intentions and motives as well as of his sufferings, trusting that this information would produce a more positive response to his leadership. He also used informational power to remind the Corinthians of the gospel that he had proclaimed and how it had transformed them. With this information, Paul empowered the Corinthians to answer and resist his opponents and their claims to power. He might have claimed informational power based on his direct access to divine revelation, as he does in other letters (cf. Rm 11:25; 16:25-26; Gl 1:16ff.; 1 Cor 15:51). ${ }^{7}$ Even though he mentions his revelations in 2 Corinthians $(12: 1,7,12)$, he does not emphasise them in the same way, perhaps, because if his opponents were indeed Jewish-Christian teachers from Jerusalem, they might well have personal knowledge of Jesus' earthly ministry, in which case their appeal to informational power would be more effective than Paul's.

Paul hardly appeals to reward power, except to state repeatedly that the Lord will commend and evaluate each one. And yet, his instructions for the Jerusalem collection (2 Cor 8-9) may implicitly function as an appeal to reward power, for this passage encourages the Corinthians to maintain their loyalty to Paul's Aegean network of churches, within which Paul and his team function as power brokers. ${ }^{8}$ This section also demonstrates the apostle's loyalty to Jerusalem. Implicitly, then, Paul offers the Corinthian community a significant place in his network of churches as well as good relations with Jerusalem as a reward for renewing their loyalty to him. This is, however, not framed in terms of competition with his opponents, neither defensively as if Paul had been critiqued on this count, nor offensively as if Paul believed this to be a key factor in legitimising his leadership. Given the tone of the arguments in 2 Corinthians $8-9$, it is unlikely that Paul intended to reclaim the Corinthian's loyalty by promising such rewards as power broker for his church network; he simply aims to renew their

7.Ephesians $3: 4-10$ and Colossians $1: 27$ also claim informational power by describing Paul's revelations as God making his mysteries known to Paul.

8.Interestingly, 2 Corinthians 8-9 feature various elements of patronage (exchange of goods, the reciprocity of patron-client relationships, Paul as power broker in his network of churches) in how Paul structures his relationship to Corinthians for the purpose of the Jerusalem connection (Jennings 2009; Joubert 2000). participation in the collection now that reconciliation is almost complete, and thus reaffirms their place in his network and their loyalty to Jerusalem. Paul then does not use his role as power broker in his church network to enhance his reward power in Corinth.

Finally, Paul appears to use coercive power in confronting his opponents in 2 Corinthians 10-13, but mostly indirectly. The initial military metaphor warns strongly of destroying strongholds and punishing any remaining disobedience (10:4-6), which affirms Paul's commitment to boldly exercise his authority upon his arrival (10:11). He fields numerous accusations against his opponents (11:3-4, 13-15, 19-20), and warns that 'if I come again I will not spare them' (13:2). Yet, he does not address them directly, but addresses the community, realising that he has no power to coerce anyone in the Corinthian church into doing anything, other than by rallying the majority of that community to his support. This strategy parallels the strategy of his opponents, who had rallied the community in support of their criticism of Paul, almost succeeding in forcibly disconnecting Paul from the Corinthian church. His opponents had access to cultural bases of power, such as patronage sponsorship and letters of recommendation, and thus had greater ability to enforce their views even if some may not have been personally convinced - such believers would have been of little social importance and had no resources to resist. In this, Paul was clearly at a disadvantage because he refused to identify with the elite and their cultural resources, thus cutting himself off from a power base that others willingly used to coerce where persuasion might not reach the desired result.

In summary, Paul limited his bases of power because he chose not to rely on informational, expert, reward or coercive power as key legitimising factors for his apostolic status as a community founder. Instead, he focused on legitimate and referent power, trusting that his claim of a divinely commissioned ministry of the Spirit as evidenced by the religious experiences of 'ordinary' believers, and his role as an ambassador of Christ's message of reconciliation, as personally embodied in his sacrificial suffering, would ultimately prove more convincing to his audience, at least the Gentiles among them, than what his opponents had to offer. Significantly, he was able to present himself precisely in his suffering as a key model for the entire community (and not only to the elite), both in their Christian living generally and in their leadership styles. Thus, Paul focused on enabling the entire membership to identify with him, his lifestyle and his message, which proved offensive perhaps most of all to the elite in their disdain for manual labour and lowly status. ${ }^{9}$

\section{Constructing Christian identity and Christian leadership}

In answering the question how Paul was able to convince the Corinthian community of the legitimacy of his authority claims, I have now compared how Paul and his opponents

9.In this, Paul practiced his own instructions about broad and respectful participation of every member of the community in the community's functions and rituals in 1 Corinthians $8-10$ and $12-14$. 
used different sources of power to legitimise their authority claims. I also described the likely response of the Corinthian congregation and their leadership to the arguments of both Paul and his opponents. This allows me to suggest that Paul's success in Corinth rested on his identification with the entire membership. Paul was a visible object lesson of the message that he preached, and provided leadership consistent with that model. This was accessible to the entire community, and thus had greater persuasive power in winning their allegiance than what his opponents were able to muster. His opponents, by contrast, appear to have been successful in the community primarily by winning the allegiance of the Corinthian leadership. Paul's model of Christian living and leadership was socially and culturally offensive to these Corinthian leaders, while the opponents proved more 'culturally sensitive': they conformed to elite expectations about eloquence and patronage, most likely believing that such practices made no essential difference in the message being proclaimed. Their criticism of Paul may or may not have been shared by most of the congregation, but given the patronage-type leadership structures, the membership had little choice but to follow.

Underlying these different authority claims and the different responses to them is a vision for the social identity of the Christian community in Corinth. Power and leadership flow along the lines of social identity (Haslam 2004; Haslam, Reicher \& Platow 2011; Turner 2005). 'Social identity' is the sense that people have about belonging to a certain social group. This is a cognitive and affective process that is highly sensitive to the social context (Haslam 2004:19ff.). Generally, some group members embody the values, beliefs and behaviours of the group more than others; they are perceived by other group members to be more prototypical. Such prototypical group members are socially more appealing, they gain in influence, and often rising to leadership status over time - as long as the group's identity and social context remains stable (Hogg 2001). This suggests that shifts in leadership models and structures interact with shifts in the community's identity. For instance, an established leader may lose ground in a changing social context, or a new leader may embody different ideals and seek to adapt the community's view of identity (Barentsen 2015).

How might this apply to the leadership conflict in Corinth? I would suggest that this conflict is not simply or primarily about a different gospel, even though Paul indirectly accuses his opponents of proclaiming a different Jesus and of being false apostles (2 Cor 11:4, 13). A point of departure is the realisation that the social identity of the Corinthian community was relatively unstable. The community had been in existence for only 6 years, its founding father had left it after 18 months and another key leader, Apollos, had also left, while the community had continued to grow. Thus, it faced significant leadership challenges in terms of social cohesion and stability. Paul's opponents offered a serious proposal for highly improved cohesion and stability, because they adjusted the community model to fit in better with cultural standards of patronage, leadership status and community formation (Harland 2003; 2009). It is no surprise, really, that the Corinthian church accepted their leadership in this period of social instability, for their proposal must have seemed neutral with respect to the message of the gospel and the identity of the community. Paul, too, was highly concerned about social cohesion and stability, as is evidenced in his letters (Rm 14:18-19; 1 Cor 1:10, Phlp 2:1-2), but his proposal for achieving social cohesion was more egalitarian (although that term is anachronistic in its application to Paul) and was most likely culturally offensive to the elite among the Christians. As Paul saw it, these different proposals were not simply different styles of leadership that led to the same goal, but each style of leadership implied a different conception of the gospel and of the social identity of the community.

The opponents, whatever their theology and personal motivations, not only provided a different type of leadership, but thereby also created a different vision of social identity, which replicated the usual social hierarchy and status distinctions within the church. It is precisely this change to which Paul so strenuously objects. Such a change in social orientation is not indifferent for his vision of identity, but it essentially presents a different model of what it means to be a leader, of what it means to be a community member. That is, Paul claims that his opponents are preaching a false Christ, because even if they communicate the same information about Christ, they act and model him differently, which implies - at least in Paul's opinion - a portrayal of Christ that identifies him with elite leaders. This Christ is unlike the Christ of Paul's own preaching and leadership style (Barentsen 2011:112-140).

Paul then presents his own ministry among the Corinthians, and his own suffering as a fitting model of Christ, not simply because his information is more accurate, but because his life and ministry embody what he teaches more faithfully. His vision for the Christian identity of the community is built on this embodiment of Christ, and implies participation of and respect for all members in a way that does not replicate the social inequalities and injustices. Of course, Paul is aware that church members still live and participate in this unequal society, which will unavoidably continue to create stress for his vision of Christian social identity. In Paul's perspective, leadership, social identity and theological content are intimately interwoven, and leadership styles are not indifferent to identity and gospel content.

\section{Conclusion and implications}

This article began by raising the question: 'How did Paul succeed in convincing the Corinthians of the legitimacy of his leadership and winning their allegiance in competition with colleague and rival leaders?' This has now been answered through a study of Paul's authority claims in 2 Corinthians, tabulated and analysed with the help of the theory of the social bases of power, with implications already drawn out on the basis of leadership and social identity theory. I would like to discuss two further implications of this study: one for 
the literary unity of 2 Corinthians and the other for today's social context of increasing leadership fluidity in many Western churches.

\section{Perception of power and the unity of argumentation in $\mathbf{2}$ Corinthians}

A social identity perspective on power emphasises the perspectival nature of how power is experienced (Simon \& Oakes 2006). For those who identify with the group and its leader, a proposal or directive from the in-group leadership tends to be received as beneficial; for those at the margins or even outside of the group, the same leadership proposals may be experienced as manipulative or coercive. This has important implications for how to evaluate Paul's strong denunciation of his remaining opponents in 2 Corinthians 10-13. Generally, a leader can only engage in such strong denunciations if he is convinced of the support of the majority of the community. If a community does not identify strongly with a particular leader, such leadership support is lacking. Consequently, the community would likely regard any proposals from this leader with a degree of suspicion, while very directive or even derogatory proposals are almost certain to be rejected as manipulative and coercive, motivating the community to close ranks and exclude this leader.

This implies that if Paul had engaged in such strong denunciations of his opponents while his leadership in Corinth was still severely contested, he would probably have been perceived as manipulative and would have succeeded only in undermining the legitimacy of his leadership even further, leading to further exclusion. That is, Paul would likely not have engaged in such denunciations in order to regain leadership status, because this strategy would have backfired. Instead, it is likely that Paul would have engaged in these denunciations only if he knew his leadership status had already been restored. And this is, of course, precisely the situation that we find in 1 Corinthians 1-7, where Paul expresses his relief and joy over the report from Titus that all is ready for reconciliation. Paul is still underway to Corinth, so that reconciliation is still only a promise, awaiting fulfilment upon Paul's arrival. Paul thus writes from the dual perspective of knowing that reconciliation is close at hand, and of exhorting them to stay true to their promise. When Paul finally engages in a more direct confrontation with his remaining opponents, he does so with the confidence that the majority will support his judgement in the matter, as, indeed, Titus had already reported to him. Thus, it is likely that the majority in Corinth had more or less expected such warnings against those who continued to resist and criticise Paul. Even if they might have found Paul's language rather strong, they would have regarded it as beneficial for the community because they now identified more strongly with Paul, believing that as suffering apostle for Corinth, he undoubtedly had their best interests in mind.

This implies that the conciliatory tone of 2 Corinthians 1-7 and the hostile tone of 2 Corinthians 10-13 are not mutually exclusive or contradictory, but rather that they are complementary and even reinforce one another. ${ }^{10}$ What is more, the hostile tone of the later chapters serves as proof that the reconciliation of the earlier chapters is broadly supported in Corinth and with a sufficiently deep commitment to stomach the denunciations as beneficial. The few reflections above on the role of the Jerusalem collection in Paul's argument with the Corinthians would underline this perspective. Altogether this contributes an important argument for the unity of the entire epistle. ${ }^{11}$

\section{Social construction and leadership models}

This study has used the perspective that leadership is not primarily a position to be secured, retained or protected, but a process of social influence in a particular group at a particular time and place, which is subject to regular interaction and debate. That is, leadership, including Paul's apostolic leadership in Corinth, is subject to social construction.

This article argued that Paul's behaviours in Corinth (not accepting money, being vulnerable, etc.) created a category of leadership that was culturally unavailable and unacceptable, while his opponents built their proposals on available and acceptable cultural models of leadership. Paul's communication strategy aims to reframe the perception of his actions in order to not only create a different cognitive framework for (the perception of) social reality, but also to create a different model of leadership that would result in his own restoration to leadership and the ousting of his competitors. Paul's reframing of leadership connects his personal and bodily experiences with the death and life of Christ, in an effort to provide strong theological anchors for a model of leadership that is otherwise unsustainable. Thus, Paul's social construction of leadership is not only framed theologically with reference to Christ, nor only socially and culturally with reference to general cultural patterns of leadership (adapting or resisting them, whatever the case may be), but also on forms of leadership practice that embody or incarnate the story of Christ afresh for the community. ${ }^{12}$

This adds an important insight to sociological perspectives that leadership at Corinth was fluid, 'charismatic' and

10.Jones, among others, points to various sections in 2 Corinthians that could function as epilogue, thereby suggesting that the letter is composed from two or more original letters (Jones 2008). However, an alternative way of interpreting this evidence is by considering whether Paul differentiated between different subgroups in his audience. Did he shift from a focus on finalizing reconciliation with subgroups in his audience. Did he shift finth a focus on finalizing reconciliation with those who now supported him in Corinth to addressing those, even if indirectly, that still resisted his leadership, as the above analysis might suggest? Differentiating between various subgroups in the audiences, along with the appropriate shift in

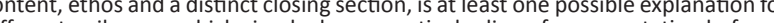
different epilogues, which simply draw a particular line of argumentation before certain audience to a close, then proceeding to the next subgroup in the audience, all of which could be accomplished within one discourse or letter.

11.Evidently, this observation does not close the discussion, but it contributes a new and important psychological perspective to the debate. A number of voices already speak for the literary unity of the letter (Bieringer 1994; Hall 2003; Long 2004; Schmeller 2013; Stegman 2005), and I join this chorus with a new argument.

12.'Social construction' here is used to indicate that particular social structures of community and leadership, and their associated meanings, are not simply given as essential or ontological categories, but are arrived at by social interaction and essential or ontological categories, but are arrived at by social interaction and negotiation. In other words, Paul could not simply appeal to a particular preexisting, ontological category of 'apostolic leader', not even by pointing to his divinely revealed and initiated apostolic role. He had to explain the social an sychological implications of his apostolic claims, convince the Corinthians of the legitimacy of this claim, and then demonstrate by principle and personal example how to effect this claim in actual social practice. For this interesting but rather complex concept, see Gergen (2009). 
structurally undetermined (MacDonald 1988), and that it generally follows cultural patterns and structures (Clarke 2006). The leadership structures in Corinth were the subject of intense debate, with different theological, sociological and cultural proposals competing for allegiance and dominance. Leadership was not a structural and fixed aspect of the situation in Corinth, but a process and positions that needed to be socially and theologically constructed, as no doubt continued to take place in the generations after Paul and the Twelve. This is, of course, not to imply that Paul intentionally followed a social constructivist approach in defending his leadership position in Corinth, but he appears to have fully realised that leadership needed to be grounded culturally and socially, as well as theologically, in order to provide the stability and cohesion that the community needed for longterm survival. Thus, a constructivist approach to leadership in biblical studies seems to align with the rhetoric and social engagement of the early Christians, as demonstrated by Paul's second letter to the Corinthians.

The above argument thus offers a case study of one congregation of only one of their congregational leaders although a very important one - at a very particular stage of community and thus of leadership formation. We cannot easily predict which arguments Paul or other apostolic leaders would use in different cities and different contexts. After all, leadership is a highly contextualised practice at the frontier of cultural creativity where community formation, intergroup relationships and influence processes intersect. Therefore, it would be inappropriate to use Paul's model of leadership in 2 Corinthians to correct centuries of church leadership practice that appears to have developed precisely along the lines that Paul so carefully avoided, namely the lines of hierarchy, status and expertise. However, if we observe that institutional ecclesial leadership is being challenged today for its reliance on hierarchy, status and expertise, at least we know we have a very interesting dialogue partner in Paul to consider how to respond to these challenges, realising that 2 Corinthians is only part of what Paul has to offer on leadership.

This reservation about a potential 'Pauline leadership model' also applies to the study of leadership in the early church. Paul cannot be played off against deutero- or trito-Paul merely on the basis of different authority claims or different leadership structures, even if Paul's leadership model in Corinth is different from the leadership structures that New Testament sources reveal for the church in Ephesus or elsewhere. As any good leader, Paul has more than one trick up his sleeve, and although we may expect a certain consistency in his leadership practice, the highly contextual nature of leadership and group identity guides us to expect a significant degree of flexibility and adaptability in Paul's leadership. Thus, different authority claims and leadership structures in the deutero- or trito-Pauline letters are no argument in themselves for differences in institutionalisation, for the development of different varieties of Christianity or for proposing different authors besides Paul.

\section{Acknowledgements Competing interests}

The author declares that he has no financial or personal relationships which may have inappropriately influenced him in writing this article.

\section{References}

Balz, H.R. \& Schneider, G. (eds.), 1990, Exegetical dictionary of the New Testament, Eerdmans, Grand Rapids, MI.

Barentsen, J., 2011, Emerging leadership in the Pauline mission: A social identity perspective on local leadership development in Corinth and Ephesus, Wipf \& Stock, Eugene, OR.

Barentsen, J., 2015, 'Church leadership as adaptive identity construction in a changing social context', Journal of Religious Leadership 15(2), 49-80.

Barentsen, J., 2016, 'Practising religious leadership', in J. Storey, J. Hartley, J.-L. Denis, P. 't Hart \& D. Ulrich (eds.), Routledge companion to leadership, pp. 260-277, Routledge, London.

Barrett, C.K., 1973, The second epistle to the Corinthians, Hendrikson, Peabody, MA.

Bieringer, R., 1994a, '2 Korinther 6,14-7,1 im Kontext des 2. Korintherbriefes. Forschungsüberblick und Versuch eines eigenen Zugangs', in R. Bieringer \& J. Lambrecht (eds.), Studies on 2 Corinthians, pp. 551-570, Peeters, Leuven.

Bieringer, R., 1994b, 'Der 2. Korintherbrief als ursprüngliche Einheit. Ein Forschungüberblick', in R. Bieringer \& J. Lambrecht (eds.), Studies on 2 Corinthians, pp. 107-130, Peeters, Leuven.

Blasi, A.J., 1991, Making charisma: The social construction of Paul's public image, Transaction Publishers, New Brunswick, NJ.

Bryman, A., 2012, Social research methods, 4th edn., Oxford University Press, Oxford.

Burtchaell, J.T., 1992, From synagogue to church: Public services and offices in the earliest Christian communities, Cambridge University Press, Cambridge.

Chow, J.K., 1992, Patronage and power: A study of social networks in Corinth, Sheffield Academic Press, Sheffield.

Clarke, A.D., 2000, Serve the community of the church: Christians as leaders and ministers, Eerdmans, Grand Rapids, Ml.

Clarke, A.D., 2006, Secular and Christian leadership in Corinth: A socio-historical and exegetical study of 1 Corinthians 1-6, 2nd edn., Paternoster, Milton Keynes.

Danker, F.W., Bauer, W., Arndt, W. \& Gingrich, F.W., 2000, A Greek-English lexicon of the New Testament and other early Christian literature, 3rd edn., University of Chicago Press, Chicago, IL.

DeSilva, D.A., 2004, An Introduction to the New Testament: Contexts, methods and ministry formation, InterVarsity, Downers Grove, IL.

Ehrensperger, K., 2007, Paul and the dynamics of power: Communication and interaction in the early Christ-movement, T \& T Clark, London.

Fairhurst, G.T. \& Grant, D., 2010, 'The social construction of leadership: A sailing guide', Management Communication Quarterly 24(2), 171-210. https://doi. org/10.1177/0893318909359697

French, J.R.P. \& Raven, B.H., 1959, 'The bases of social power', in D. Cartwright (ed.), Studies in social power, pp. 150-167, Institute of Social Research, Ann Arbor, MI.

Garland, D.E., 1999, 2 Corinthians, Broadman \& Holman, Nashville, TN.

Garland, D.E., 2003, 1 Corinthians, Baker Academic, Grand Rapids, MI.

Gergen, K.J., 2009, An invitation to social construction, 2nd edn., Sage, Los Angeles, CA.

Glancy, J.A., 2004, 'Boasting of beatings (2 Corinthians 11:23-25)', Journal of Biblical Literature 123(1), 99-135. https://doi.org/10.2307/3268552

Gloer, W.H., 1989, '2 Corinthians 5:14-21', Review and Expositor 86(3), 397-405. https://doi.org/10.1177/003463738908600308

Hall, D.R., 2003, The unity of the Corinthian correspondence, T \& T Clark, London.

Hanges, J.C., 2011, Paul, founder of churches. A study in light of the evidence for the role of 'founder-figures' in the Hellenistic-Roman period, Mohr-Siebeck, Tübingen.

Harland, P.A., 2003, Associations, synagogues, and congregations: Claiming a place in ancient Mediterranean society, Fortress, Minneapolis, MN.

Harland, P.A., 2009, Dynamics of identity in the world of the early Christians: Associations, Judeans, and cultural minorities, T \& T Clark, New York.

Harris, M.J., 2005, The second epistle to the Corinthians: A commentary on the Greek text, Eerdmans, Grand Rapids, MI.

Haslam, S.A., 2004, Psychology in organizations: The social identity approach, 2nd edn., Sage, London.

Haslam, S.A., Reicher, S. \& Platow, M.J., 2011, The new psychology of leadership: Identity, influence and power, Psychology Press, New York.

Heitink, G., 2001, Biografie van de dominee, Ten Have, Baarn.

Herrington, J., Bonem, M. \& Furr, J.H., 2000, Leading Congregational change: A practical guide for the transformational journey, Jossey-Bass, San Francisco, CA.

Hogg, M.A., 2001, 'A social identity theory of leadership', Personality and Socia Psychology Review 5(3), 184-200. https://doi.org/10.1207/S15327957PSPR0503_1 
Holifield, E.B., 2007, God's ambassadors: A history of the Christian clergy in America, Eerdmans, Grand Rapids, MI.

Holmberg, B., 1978, Paul and power: The structure of authority in the primitive church as reflected in the Pauline epistles, CWK Gleerup, Lund.

Horrell, D.G., 1995, 'The development of theological ideology in Pauline Christianity: A structuration theory perspective', in P.F. Esler (ed.), Modelling early Christianity: Social-scientific studies of the New Testament in its context, pp. 224-236, Routledge, London.

Horrell, D.G., 1996, The social ethos of the Corinthian correspondence interests and ideology from 1 Corinthians to 1 Clement, T \& T Clark, Edinburgh.

Horrell, D.G., 1997, 'Leadership patterns and the development of ideology in early Christianity', Sociology of Religion 58, 323-341. https://doi.org/10.2307/3711919

Hybels, B., 2012, Courageous leadership: Field-tested strategy for the $360^{\circ}$ leader exp. edn., Zondervan, Grand Rapids, MI.

Jennings, M.A., 2009, 'Patronage and rebuke in Paul's persuasion in 2 Corinthians 8-9', Journal of Greco-Roman Christianity and Judaism 6, 107-127.

Jones, I.H., 2008, 'Rhetorical criticism and the unity of 2 Corinthians: One "epilogue", or more?' New Testament Studies 54(4), 496-524.

Joubert, S.J., 2000, Paul as benefactor: Reciprocity, strategy and theological reflection in Paul's collection, Mohr Siebeck, Tübingen.

Joubert, S.J., 2015, “'Walking the talk": Paul's authority in motion in 2 Corinthians 10-13 / "Om jou praat te loop": Paulus se outoriteit aan die beweeg in 2 Korintiërs 10-13', In die Skriflig 49(2), 1-7.

Knippenberg, B.V. \& Knippenberg, D.V., 2005, 'Leader self-sacrifice and leadership effectiveness: The moderating role of leader prototypicality', Journal of Applied Psychology 90(1), 25-37. https://doi.org/10.1037/0021-9010.90.1.25

Long, F.J., 2004, Ancient rhetoric and Paul's apology: The compositional unity of 2 Corinthians, Cambridge University Press, Cambridge.

MacDonald, M.Y., 1988, The Pauline churches: A socio-historical study of institutionalization in the Pauline and deutero-Pauline writings, Cambridge University Press, Cambridge.

Martin, D.B., 1991, 'Tongues of angels and other status indicators', Journal of the American Academy of Religion 59, 563-569. https://doi.org/10.1093/jaarel/ LIX.3.547

Martin, R.P., 1986, 2 Corinthians, Word, Waco, TX

Maxwell, J.C., 1999, The 21 indispensable qualities of a leader: Becoming the person that people will want to follow, Nelson, Nashville, TN.

Mitchell, M.M., 1991, Paul and the Rhetoric of Reconciliation: An exegetical investigation of the language and composition of 1 Corinthians, Mohr Siebeck, Tübingen.
Raven, B.H., 2008, 'The bases of power and the power/interaction model of interpersonal influence', Analyses of Social Issues and Public Policy 8(1), 1-22. https://doi.org/10.1111/j.1530-2415.2008.00159.x

Schmeller, T., 2013, 'No bridge over troubled water? The gap between 2 Corinthians 1-9 and 10-13 revisited', Journal for the Study of the New Testament 36(1), 7384. https://doi.org/10.1177/0142064X13495136

Schütz, J.H., 1975, Paul and the anatomy of apostolic authority, Cambridge University Press, London.

Simon, B. \& Oakes, P.J., 2006, 'Beyond dependence: An identity approach to social power and domination', Human Relations 59(1), 105-139. https://doi. org/10.1177/0018726706062760

Stegman, T., 2005, The character of Jesus: The linchpin to Paul's argument in 2 Corinthians, Editrice Pontificio Istituto Biblico, Rome.

Stenschke, C.W., 2015, 'The leadership challenges of Paul's collection for the saints in Jerusalem, Part I: Overcoming the obstacles on the side of the gentile Christian donors', Verbum et Ecclesia 36(1), 1-14. https://doi.org/10.4102/ve.v36i1.1406

Talbert, C.H., 2002, Reading Corinthians: A literary and theological commentary on 1 and 2 Corinthians, rev. edn., Smyth \& Helwys, Macon, GA.

Theissen, G., 1982, The social setting of Pauline Christianity: Essays on Corinth, transl. J.H. Schütz, Fortress, Philadelphia, PA.

Thiselton, A.C., 2000, The first epistle to the Corinthians: A commentary on the Greek text, Paternoster, Carlisle.

Tierney, W.G., 1996, 'Leadership and postmodernism: On voice and the qualitative method', The Leadership Quarterly 7(3), 371-383. https://doi.org/10.1016/ S1048-9843(96)90026-0

Turner, J.C., 2005, 'Explaining the nature of power: A three-process theory', European Journal of Social Psychology 35(1), 1-22. https://doi.org/10.1002/ejsp.244

Uhl-Bien, M., Marion, R. \& McKelvey, B., 2007, 'Complexity leadership theory: Shifting leadership from the industrial age to the knowledge era', The Leadership Quarterly 18(4), 298-318. https://doi.org/10.1016/j.leaqua.2007.04.002

Uhl-Bien, M. \& Ospina, S. (eds.), 2012, Advancing relational leadership research: A dialogue among perspectives, Information Age, Charlotte, NC.

van den Hoonaard, W.C., 2008, 'Sensitizing concepts', in L.M. Given (ed.), The Sage encyclopedia of qualitative research methods, pp. 813-816, Sage, Thousand Oaks, CA.

von Campenhausen, H.F., 1997, Ecclesiastical authority and spiritual power in the church of the first three centuries, transl. J.A. Baker, reprint of 1969 ed., Hendrickson, Peabody, MA.

Winter, B.W., 2002, Philo and Paul among the sophists: Alexandrian and Corinthian responses to a Julio-Claudian movement, 2nd edn., Eerdmans, Grand Rapids, MI. 